\title{
SINGLE-STAGE TREATMENT OF ANEURYSM OF THE DISTAL AORTIC ARCH AND PROXIMAL DESCENDING AORTA USING THE FROZEN ELEPHANT TRUNK PROCEDURE. CASE REPORT
}

\author{
Sasko Jovev $^{1}$, Vasil Papestiev ${ }^{1}$, Marjan Shokarovski ${ }^{1}$, Stefanija Hadzievska ${ }^{1}$, \\ Nadica Mehmedovic ${ }^{1}$, Nikola Lazovski ${ }^{1}$, Venko Filipce ${ }^{2}$, Petar Risteski ${ }^{3}$ \\ ${ }^{1}$ University Clinic for Cardiac Surgery, Skopje, N. Macedonia \\ ${ }^{2}$ University Clinic for Neurosurgery, Skopje, N. Macedonia \\ ${ }^{3}$ Department of Thoracic and Cardiovascular Surgery, University Hospital Frankfurt, Goethe University, Frankfurt, Germany
}

Corresponding author: Sasko Jovev MD PhD, Univesity Clinic for Cardiac Surgery, Majka Teresa b.b, 1000 Skopje, Republic of Macedonia, Tel. ++389 75389 002, E mail: Jovev99@yahoo.com

\begin{abstract}
Aneurysms of the thoracic aorta involving the distal arch and the proximal descending aorta have traditionally been treated with two open procedures. During the first stage, the aortic arch pathology has been addressed through a median sternotomy. Several weeks or months later, a second stage followed and included completing the repair of the descending aorta through a lateral thoracotomy.

We, herein, report a single stage repair of an aneurysm involving the distal aortic arch and the proximal descending aorta using the frozen elephant trunk operative technique. Vascular hybrid stent graft prosthesis, specifically designed for treatment of extensive aortic aneurysms, has been used to replace the arch component and exclude the descending aorta component of the aneurysm through a median sternotomy, using bilateral antegrade cerebral perfusion and mild systemic hypothermia for intraoperative organ protection.
\end{abstract}

Keywords: frozen elephant trunk, aortic arch, aneurysm, aorta

\section{INTRODUCTION}

A saccular aortic aneurysm appears as an asymmetrical dilation, usually involving one side and rarely extending over two anatomical segments of the aorta. They are often caused by trauma or a large penetrating aortic ulcer. Prompt repair is indicated for symptomatic saccular aneurysms despite the maximal diameter or documented growth tendency. Asymptomatic aneurysms are usually treated on an elective basis as soon as the maximal diameter exceeds $2.75 \mathrm{~cm} / \mathrm{m} 2$ as recommended [1].

The treatment of aortic aneurysms has usually involved resection of the diseased aortic segment and replacement with a vascular prosthesis [2]. The pa- thology involving the distal aortic arch and proximal descending aorta has traditionally been treated with two open procedures or stages, through a median sternotomy or lateral thoracotomy [3].

The frozen elephant trunk procedure, combining conventional open aortic repair and endovascular stenting, has been introduced [4], promptly popularised [5] and recently recommended [6] as a single-stage treatment of choice for patients with extensive aortic disease.

In this paper, we present our first experience with this procedure, without any improvements in 
the technique apart from what has been published in the literature up until now.

\section{CASE REPORT}

A sixty-one-year-old female presented in our department with a complaint of syncope, chest pain, and tachycardia. The anamnestic findings revealed pain in the left hemi-abdomen under the 12th rib, after a fall as a result of lost consciousness. The patient is a smoker, allergic to Ketoprofen. A year ago she was diagnosed with hypothyroidism, treated with levothyroxin. Also, cholecystectomy was performed $30 \mathrm{y}$ ago. The ultrasonography of the carotid arteries showed normal speed flow without any significant changes and stenosis. The peripheral magistral blood vessels were also examined with ultrasonography and no changes were observed. A chest X-ray performed in the emergency department showed a widening shadow in the middle of the mediastinum with clear contours, a result of saccular aneurism, which indicated further diagnostic procedures, Computer tomography $(\mathrm{CT})$ of the thorax and the aorta.

The CT exam demonstrated a saccular aneurysm, with a maximal diameter of $73 \mathrm{~mm}$ (Fig. 1), extending over the distal aortic arch and involving further the proximal descending aorta. Visceral and supraaortic blood vessels were haemodinamically normal.

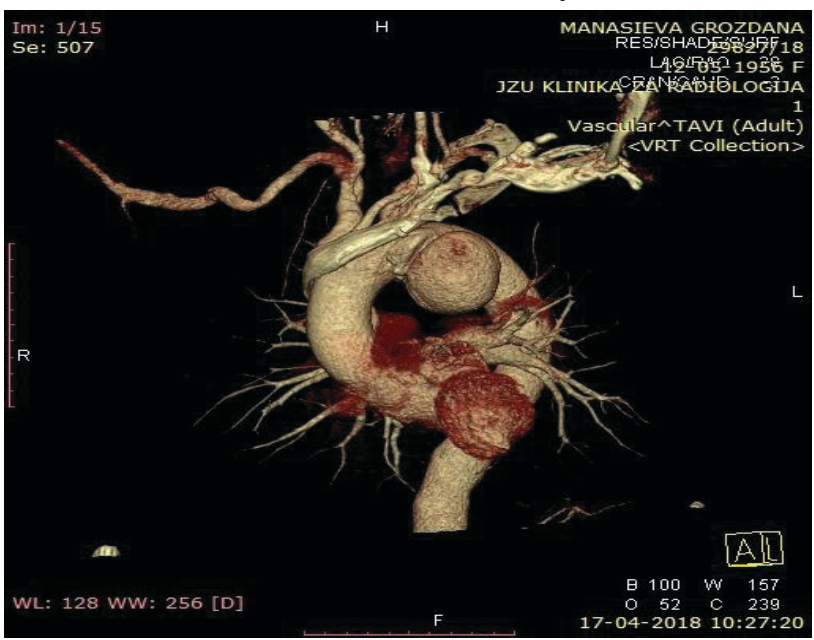

Fig. 1.

The other anatomical segments of the thoracoabdominal aorta were normal. The cortical cysts in the superior part of the left kidney were also found. The other visceral organs were without focal changes. The electrocardiography, transthoracic echocardiography, coronary angiography, and laboratory findings were unremarkable.
A single stage operative treatment with total arch replacement and antegrade stenting of the descending aorta was indicated. The preoperative CT scan of the thorax and the aorta was used to plan the operative approach, the extent of resection of the aortic pathology and the distal extent of the exclusion of the aneurysm. Furthermore, the distal landing zone was identified and properly sized. A $15 \%$ oversizing of the stent component of the hybrid prosthesis (E-vita OPEN PLUS Hybrid Stent Graft System, Jotec, GmbH, Hechingen, Germany) was used to provide adequate sealing at the distal landing zone and to avoid type Ib endoleak.

After a median sternotomy and administration of heparin (400 IE/kg), the right axillary artery was directly cannulated in the deltopectoral groove with a flexible arterial cannula. For venous drainage, following pericardiotomy, the right atrium was cannulated with a two-stage cannula. The brachiocephalic left common carotid and left subclavian artery were dissected free and encircled with elastomers. The aortic arch was circumferentially dissected free up to zone 2. Further dissection of the aortic arch was not performed in order to preserve the recurrent laryngeal nerve. For the same reason, the distal anastomosis with the hybrid prosthesis was planned in zone 2 . Thus, a de-branching of the left subclavian artery was performed during cooling the patient down to the target temperature of $28 \mathrm{C}$.

To perform the de-branching of the left subclavian artery, we clamped and transacted the artery $3 \mathrm{~cm}$ distal from its origin. A Dacron vascular graft with $7 \mathrm{~mm}$ diameter was sewn directly to the subclavian artery using an end-to-end anastomosis with a $5 / 0$ polypropylene suture. The proximal stump was directly closed. The $7 \mathrm{~mm}$ vascular prosthesis was cannulated with an additional flexible cannula and connected via a Yarm to the arterial return circuit of the cardiopulmonary bypass - therewith an antegrade flow through the left subclavian artery was established in order to have good perfusion of the spinal cord during a period of moderate hypothermic lower body circulatory arrest.

After a cardioplegic arrest, the arterial flow of the main circuited was reduced and elastomers were used to occlude the origins of the brachiocephalic trunk and the left common carotid artery. The aortic clamp was removed and the aortic arch was resected up to zone 2. The elastomer loop snared around the left common carotid artery was temporarily loosened at this point and a flexible arterial cannula was placed inside the vessel for additional perfusion of the left hemisphere. This arterial line was simply connect- 
ed as a side branch to the arterial circuit. Selective antegrade cerebral perfusion was conducted with a perfusate temperature of $28^{\circ} \mathrm{C}$ in a pressure controlled manner. The perfusion pressure was controlled at the pump unit and kept at 80 to $90 \mathrm{mmHg}$ as measured on the main pump, and corresponded with a $60 \mathrm{mmHg}$ pressure as measured with the left radial artery catheter. Neurovascular monitoring consisted of cerebral saturation assessment using near-infrared spectroscopy over both frontal cerebral cortexes. We used the INVOS (Somanetics Corporation, MI, USA), which measures the regional oxygen saturation $\left(\mathrm{rSaO}_{2}\right)$ in percentage, representing a valuable neurovascular monitoring tool.

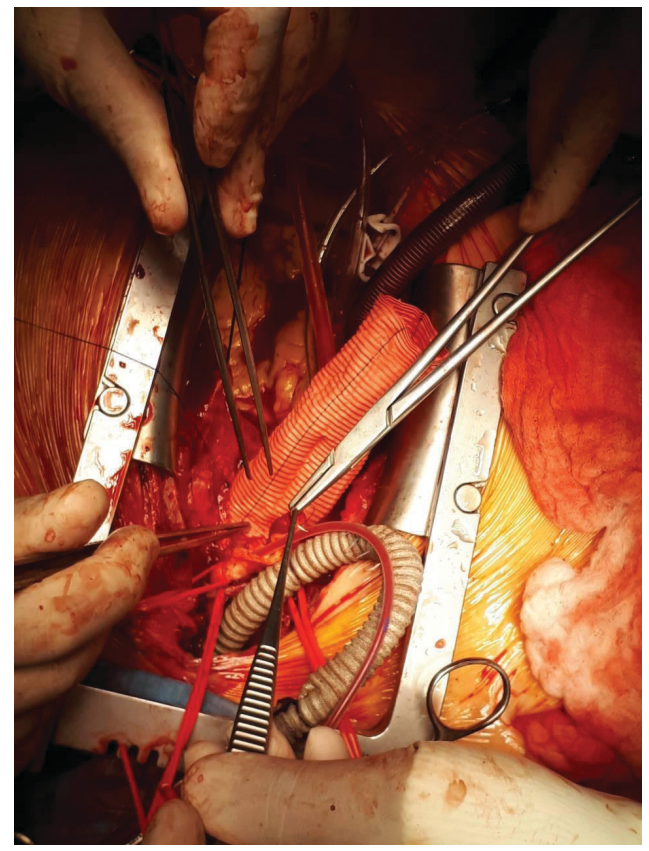

Fig. 2.

To exclude the aneurysm from the circulation, an antegrade delivery of the stent graft through the opened distal aortic arch was performed and further deployed under direct vision. The stent-graft was sutured in zone 2 using a continuous suture technique with a polypropylene $4 / 0$. Afterward, the invaginated vascular graft was pooled back from the stent and used to replace the aortic arch. The brachiocephalic and left common carotid artery were re-implanted using the Carrel island technique with a continuous polypropylene $4 / 0$ suture. Following de-airing of the prosthesis, the graft was clamped, the perfusion of the whole body was resumed via the brachiocephalic trunk, rewarming was initiated and the proximal anastomosis of the Dacron graft with the ascending aorta was performed in a usual fashion. The procedure was completed with the proximal anastomosis of the de-branched left subclavian artery on the ascending aorta (Fig. 2).
The patient was weaned from the ventilator within 12 hours and underwent an unremarkable postoperative course. She was discharged on the 9th postoperative day. A control CT scan of the aorta demonstrated complete exclusion and thrombosis of the aneurysm without any endoleak (Fig. 3).

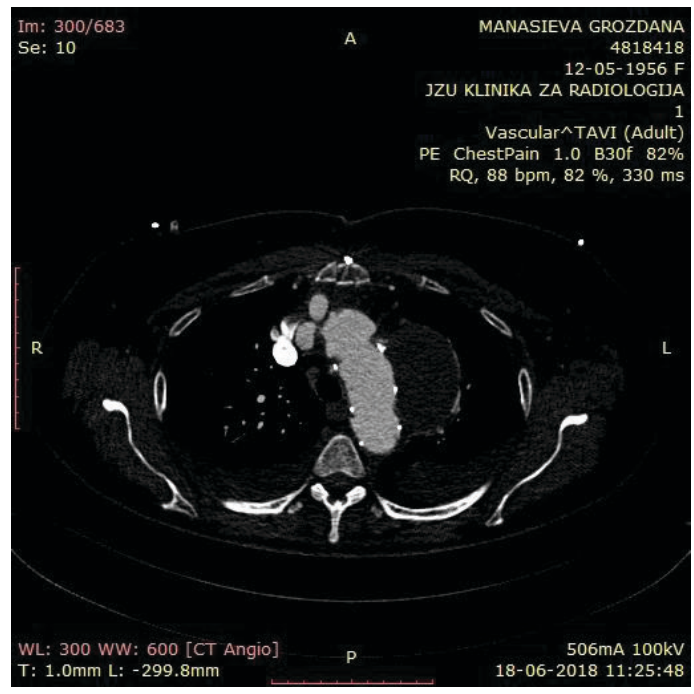

Fig. 3.

\section{DISCUSSION}

Aortic aneurysms involving the distal aortic arch and a variable extent of the descending aorta present a significant challenge for the aortic surgeon. From different types of two-stage procedures to single-stage procedures, the era of aortic surgery has had a significant improvements trough the last three decades.

With the advent of the thoracic endovascular aneurysm repair (TEVAR), the second stage procedure after performing classical elephant trunk operation could be done endovascular, avoiding or minimizing complications from the open second stage procedure. Lower morbidity and mortality were reported using this approach [10]. Another approach is a two-stage procedure of arch de-branching first, done with sternotomy, followed by endovascular repair of the diseased arch and descending aorta [11].

The frozen elephant trunk (FET) operation has been developed in order to overcome all of the obstacles and disadvantages of the previous techniques in the treatment of complex thoracic aortic diseases through the combination of surgical and endovascular techniques. It provides for the treatment to be completed through a single incision, usually median sternotomy, even though a less in- 
vasive approach like an upper mini-sternotomy may also be used [4]. The hybrid prosthesis includes two components sutured together: a woven vascular graft and a stent. The grafted part is $50-70 \mathrm{~mm}$ long, made of polyester fabric, and offers zero-porosity. The stent part, being 130-160 mm long, treats the surgically inaccessible part of the thoracic aorta through a single incision like median sternotomy. It also provides for an excellent landing zone for future TEVAR procedure, if necessary $[7,8]$.

Technological obstacles are continuously upgrading and for the time being available grafts for FET technique are E-vita open plus, Thoraflex Hybrid, Cronus and J Graft. Technically none of them are completely perfect for variable aortic pathology, so the development of stent-grafts is pointed on simple, flexible and long-lasting systems [18].

The ideal stent-graft should combine treatment from dissection and aneurysm to associated pathologies like Kommerell diverticulum and coarctation. The ideal graft should provide satisfactory early and late outcomes for any patient, regardless of etiology, anatomy, acuity and patient size, with minimal surgical risks, especially in terms of spinal cord injury, stroke, and endoleak [18].

Ius F. et all, compared the clinical outcomes, taking the age, cardiopulmonary time and selective antegrade cerebral perfusion time into account. (Table 1) [17].

As with other complex aortic procedures, as well as shown above, organ protection is mandatory for optimal outcome. We used mild systemic hypothermia at $28^{\circ} \mathrm{C}$ and bilateral antegrade cerebral perfusion in a pressure-controlled fashion. Several groups have reported improved patient outcomes using this strategy $[6,12]$. We also believe that bilateral antegrade cerebral perfusion is mandatory because of the low incidence of stroke and the possibility to extend the operative time in complicated cases. It also gives us the opportunity to employ mild systemic hypothermia at $28^{\circ} \mathrm{C}$ with less bleeding complications. Separate cannulation and perfusion of the left subclavian artery provides us with better spinal cord protection, and lower incidence of paraplegia, even with longer times of lower body circulatory arrest [15].

Clinical outcomes have considerably improved with the use of the frozen elephant trunk technique primarily related to the optimization of the preoperative planning and the improvement of the intraoperative organ protection strategy $[14,15]$.

Di Bartolomeo et al, explained that the FET technique offers the advantage of being able to close the primary entry tear in the distal arch and in the proximal descending aorta, decompressing the false lumen, thus, achieving probable definitive repair with thrombosis of the false lumen, reducing aortic complications or even reoperation. Also, in Stanford B dissection, when a proximal landing zone for graft is unavailable, frozen elephant trunk can be considered an alternative. They also described the significant improvement in clinical outcomes comparing patients who underwent cET against those with FET. Assuming all of the possible risks, FET procedure is far more a leader, decreasing the mortality rate for almost a half compared to the ET procedures. The 30 days mortality was 19.2 cET group vs 8.7 FET group. The mid-term survival had no significant changes. Although the percentage of patients with paraplegia was similar (3.7\% FET vs $4.0 \% \mathrm{cET})$ the authors concluded that considering the high incidence of post-operative paraplegia, hypothermia should be used if arrest is prolonged. According to the fact that the FET procedure allows formation of thrombus above the landing zone which decreases the stress-wall and growth of the aorta, single stage FET procedure is becoming a promising procedure in the future [13].

Table 1. Comparison of clinical outcomes of currently available open stented grafts

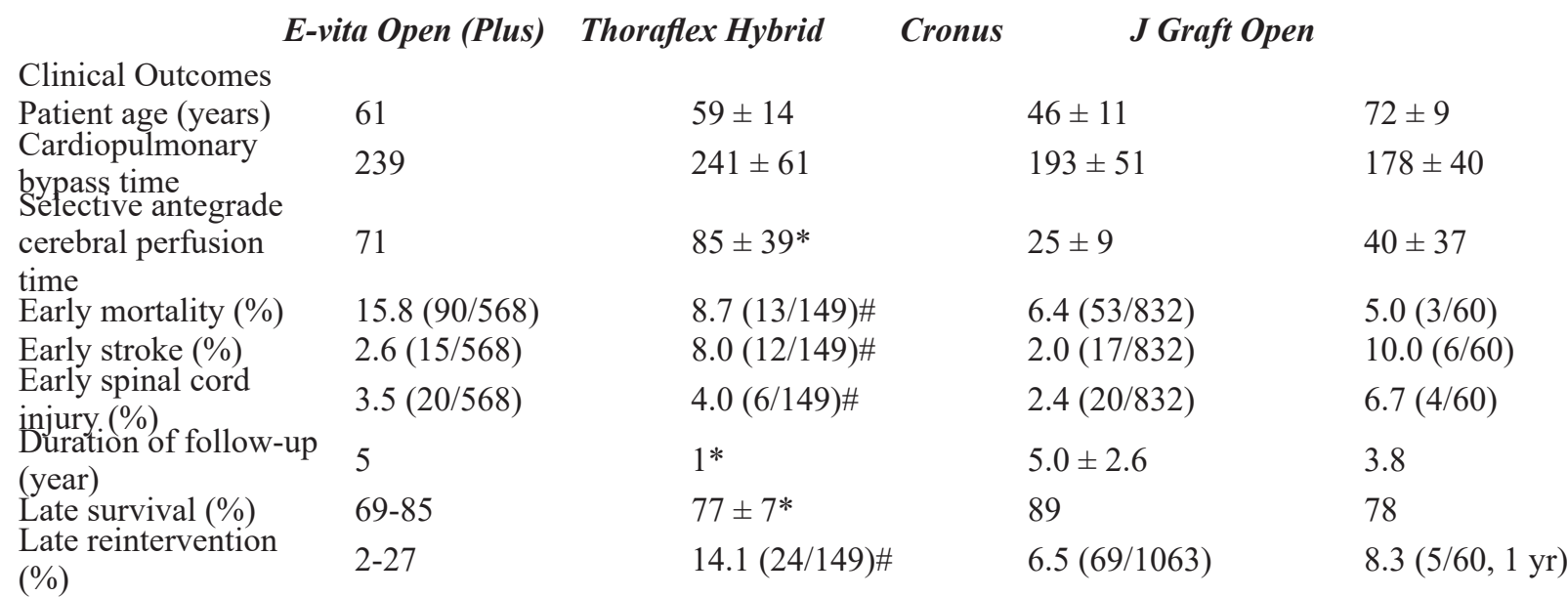


Nowadays, this treatment can be offered to patients with single digit mortality or neurologic morbidity rate [16].

\section{CONCLUSION}

Electrodermal response (EDR) is a complex reactThe frozen elephant trunk as single stage procedure combines the conventional surgery of the ascending aorta and arch as well as hybrid prosthesis for the proximal part of the thoracic aorta. This provides repair of the larger segment of the aorta, limiting the invasiveness of second procedure or reintervention. Taking into account the expansion of indications for FET technique, the technology should develop more eligible systems which will provide better clinical outcomes for the patients. Even though a lot of studies comparing the types of prosthesis are published in literature, we believe that further studies are needed in this field.

\section{REFERENCES}

1. Erbel R, Aboyans V, Boileau C, et al. 2014. 2014 ESC Guidelines on the diagnosis and treatment of aortic diseases. European Heart Journal; 35: 2873-2926.

2. Luehr M, Peterss S, Zierer A, Pacini D, et al. 2018. Aortic events and reoperations after elective aortic arch surgery: incidence, surgical strategies and outcomes. Eur j Cardiothorac Surg 1; 53(3): 519-524.

3. Estrera AL, Sandhu HK, Miller CC, et al. 2014. Repair of extensive aortic aneurysms :a single center experience using elephant trunk technique over 20 years. An Surg; 260(3): 510-6.

4. Risteski P, El-Sayed Ahmad A, Monsefi N, et al. 2017. Minimally invasive aortic arch surgery:Early and late outcomes Int J Surg; 45; 113-117.

5. Grabenwoger M, Alfonso F, Bachet J, et al. 2012. Thoracic Endovascular Aortic Repair TEVAR for treatment of aortic diseases: a position statement from European Association for Cardio-Thoracic Surgery EACTS and the European Society of Cardiology ESC, in collaboration with Europian Association of Percutaneus Cardiovascular Interventions EAPCI, European Heart Journal Advance Access.

6. Zierer A, El Sayed Ahmad A, Papadopoulos N, et al. 2017. Fifteen years of surgery for acute type A dissection in moderate to mild systemic hypothermia Eur J Cardiothorac Surg; 51 (1): 97-103.
7. Borst HG, Walterbusch G, Shaps D, et al. 1983. Extensive aortic replacement using „elephant trunk“ prosthesis. Thorac Cardiovasc Surg; 31: 37-40.

8. Etz CD, Plestis KA, Kari FA, et al. 2008 Staged repair of thoracic and thoracoabdominal aortic aneurysms using the elephant trunk technique: a consecutive series of 215 first stage and 120 complete repairs. Eur J Cardiothorac Surg; 34: 605-615.

9. Doss M, Woehleke T, Wood JP, Martens S, Greinecker GW, Moritz A. 2003. The clamshell approach for the treatment of extensive thoracic aortic disease. J Thorac Cardiovasc Surg; 126(3): 814-7.

10. Castrovinci S, Murana G, de Maat GE,et al. 2015. The classic elephant trunk technique for staged thoracic and thoracoabdominal aortic repair: long-term results. Thorac Cardiovasc Surg; 149(2): 416-22.

11. De Rango P, Cao P, Ferrer C, et al. 2014. Aortic arch debranching and thoracic endovascular repair. J Vasc Surg; 59(1): 107-14.

12. Preventza O, Price MD, Simpson KH, et al. 2015. Hemiarch and total arch surgery in patients with previous repair of acute type I aortic dissection. Ann Thorac Surg; 100: 833-9.

13. Di Bartolomeo R, Murana G, Di Marco L, Pantaleo A, Alfonsi J, Leone A et al. Frozen versus conventional elephant trunk technique: application in clinical practice. Eur J Cardiothorac Surg 2017; 51: i25-i33.

14. Shrestha M, Beckmann E, Krueger H, et al. 2015. The elephant trunk is freezing: The Hannover experience. J Thorac Cardiovasc Surg; 149(5): 1286-93.

15. Shrestha M, Bachet J, Bavaria J, et al. 2015. Current status and recommendations for use of the frozen elephant trunk technique: a position paper by the Vascular Domain of EACTS. Eur J Cardiothorac Surg; 47(5): 759-69.

16. El-Sayed Ahmad A, Risteski P, Ay M, Papadopoulos N, Moritz A, Zierer A. 2018. Moderate hypothermic circulatory arrest $\left(\geq 28^{\circ} \mathrm{C}\right)$ with selective antegrade cerebral perfusion for total arch replacement with frozen elephant trunk technique. Thorac Cardiovasc Surg. [Epub ahead of print]

17. Ius F, Fleissner F, Pichlmaier M, Karck M, Martens A, Haverich A, et al. Total aortic arch replacement with the frozen elephant trunk technique: 10-year follow-up single-centre experience. Eur J Cardiothorac Surg. 2013; 44: 949-957. DOI: $10.1093 /$ ejcts/ezt229

18. Wei-Guo Ma, MD1,2, Jun Zheng, MD1, Li-Zhong Sun, MD1*, John A. Elefteriades, Open Stented Grafts for Frozen Elephant Trunk Technique: Technical Aspects and Current Outcomes. AORTA, August 2015, Volume 3, Issue 4: 122-135 


\title{
Резиме
}

ТРЕТМАН НА АНЕВРИЗМА НА ДИСТАЛЕН ЛАК НА АОРТА И ПРОКСИМАЛНА ДЕСЦЕДЕНТНА АОРТА ВО ЕДЕН АКТ СО Т.Н. „FROZЕN ЕLЕPHАNT TRUNК“ ПРОЦЕДУРА. ПРИКАЗ НА СЛУЧАЈ

\author{
Сашко Јовев ${ }^{1}$, Васил Папестиев ${ }^{1}$, Марјан Шокаровски ${ }^{1}$, Стефанија Хаџиевска ${ }^{1}$, \\ Надица Мехмедовиќ ${ }^{1}$, Никола Лазовски ${ }^{1}$, Венко Филипче르, Петар Ристески ${ }^{3}$ \\ ${ }^{1}$ Универзитетска Клиника за Државна Кардиохирургија, Скопје, С. Македонија \\ 2 Универзитетска Клиника за Неврохирургија, Скопје, С. Македонија \\ ${ }^{3}$ Оддел за Торакална и Кардиоваскуларна хирургија, Универзитетска Болница Франкфурт, Гете \\ Универзитет, Франкфурт, Германија
}

Аневризмите на торакалната аорта, кои го зафаќаат дисталниот лак на аортата и проксималната десцендентна аорта, традиционално беа третирани со две одвоени отворени хируршки процедури. Во првата фаза, преку медијална стернотомија, третирана е патологијата на лакот на аортата. Неколку недели или месеци подоцна, следува втората фаза, во која, преку латерална торакотомија, се довршува и поправката на десцендентната аорта.

Во овој случај прикажуваме поправка на аневризма што го опфаќа дисталниот лак на аортата и проксималната десцендентна аорта, во една фаза, со употреба на оперативна техника т.H. „Frozen Elephant trunk“.

За замена на аневризматскиот дел од лакот на аортата и исклучување на аневризматскиот дел од десцендентната аорта, преку медијална стернотомија, поставена е хибридна васкуларна стент графт протеза, специјално дизајнирана за третман на екстензивни аневризми на овој дел од аортата, применувајќи билатерална антеградна церебрална перфузија и умерена (средна) системска хипотермија за интреоперативна органска протекција.

Клучни зборови: „frozen elephant trunk“, аортен лак, аневризма, аорта 